\title{
ТВОРЧІСТЬ ЯК ЗАСІБ САМОРЕАЛІЗАЦІЇ ОСОБИСТОСТІ В ПЕРІОД ДОРОСЛІШАННЯ
}

УДК: 159.923.2-053.6

\section{Просандеєва Людмила Євгенівна}

Доктор психологічних наук, завідувач кафедри психології Київського національного університету культури і мистеитв, м. Київ (Украӥна)

\begin{abstract}
Анотація. $\quad$ У статті висвітлюється проблема творчості особистості в період дорослішання. Розкривається взаємозв'язок понять творчості та самореалізачії, а також їх роль у розвитку підростаючої особистості. Особливу увагу зосереджено на аналізі творчоі самореалізачії особистості, динаміка якої полягає в тому, щүо незалежно від індивідуальних ліній розвитку, людина реалізує певні стратегї поведінки - адаптативну-неадаптативну, альтруїстичну-егоїстичну, конструктивну-деструктивну. Зміна стратегій відповідає певному віковому етапу, коли вирішуються основні завдання віку. Актуалізація подібних стратегій творчої самореалізації співвідноситься із закономірним виникненням, розииренням, узгодженістю власного «Я» у період дорослішання. Моделюючи процес творчої самореалізації людини від дошкільного віку до юнацького, можна чітко побачити поступову динаміку системи внутрішнього «Я», щчо пов'язана з вибором стратегій поведінки у період дорослішання.
\end{abstract}

Ключові слова: творчість, самореалізачія особистості, динаміка творчої самореалізації, стратегї самореалізації.

Постановка проблеми. Модернізація освітньої системи України висуває нові вимоги, що стосуються розвитку творчості підростаючої особистості, гармонізації емоційного інтелекту, поліпшення її комунікативних здібностей. Проблема творчості особистості та джерел іï походження виступає центральним питанням психологічної науки. Пошук відповідей на запитання, що спонукає особистість до творчої самореалізації, призводить до побудови нових наукових парадигм, теорій i концепцій.

Сьогодні поняття «творчість» $є$ найпоширенішим поняттям, яке дозволяє висловити основну ідею співвідношення суспільства i культури - ідею особистості. Відтак, творчість - це творення за допомогою синтетичних художніх образів, символів, в яких з особ- 
ливою глибиною втілюються людські ідеали, соціокультурні цінності, моральні норми. Художня творчість - це створення естетичних цінностей, вміння доторкнутися до внутрішнього «Я» людини, що стимулює іiї емоції та гармонізує настрій. При цьому у розвитку творчого потенціалу надзвичайно велике значення має уява та емоційно-образна сфера людини. Як відомо, творчість реалізується через такі види мистецтва як музика, театр, кіно, живопис, графіка, архітектура та ін.), літературу (проза, поезія). Творчість завжди пов'язана з індивідуальністю людської особистості, вона пронизана суб'єктивністю, і відкриває шляхи спілкування $з$ людською душею. Саме творчість синтезує особливе світорозуміння і світовідчуття людини, пізнання і переживання нею світу. Творчість розширює межі людського світу й оптимізує саморозвиток особистості у відповідності з прийнятим ідеалом. Як відомо, творчість реалізується через такі види мистецтва як музика, театр, кіно, живопис, графіка, архітектура та ін., літературу (проза, поезія). Творчість завжди пов'язана 3 виробленням нових цілей (завдань) і відповідних до них засобів, а також 3 досягненням вже відомих цілей (завдань) з допомогою нових засобів $[1 ; 2]$.

Аналіз літературних джерел 3 досліджуваної проблеми показав, що поняття «творчість» розглядається також як динамічна система, що постійно розвивається. Проте творчість особистості може динамічно розвивати- ся лише спираючись на їі активну діяльність, ініціативність, уміння всебічно виявити власний внутрішній потенціал. Саме залежно від характеру й змісту творчої діяльності може активно розгортатися внутрішня самореалізація особистості. Освоєння соціального досвіду, знаків, символів, оволодіння власною соціальною сутністю, вироблення способів поводження із власним «Я» при оцінці власних дій, уміння придивлятися до себе, приміряти себе до навколишнього світу, рефлексія на власні дії та поведінку, - все це пов'язано 3 творчою самореалізацією себе серед інших людей. 3 цього випливає, що становлення якісно нового рівня розвитку особистості обумовлено трансформацією вихідної діяльності в діяльність більш значущу для людини, що відповідає іï потребі у творчій самореалізації.

Незважаючи на досить грунтовну базу досліджень, заявлена проблема все ще потребує вивчення, особливо з огляду на стан психологічної культури в українському суспільстві. Тому метою статті є розкриття творчості як засобу самореалізації особистості в період дорослішання, а саме: моделювання процесу творчої самореалізащії людини від дошкільного віку до юнацького.

\section{Аналіз публікацій та досліджень.}

Проведений теоретичний аналіз став основою якісної інтерпретації поглядів зарубіжних вчених на процес творчої самореалізації людиною своїх смисложиттєвих і ціннісних орієнтацій, намагання самоствердити свої здатності 
й здібності. Таку самореалізацію А. Маслоу називав самоактуалізацією, самовіддачею, само здійсненням [9]. Подібної точки зору дотримувався й К. Роджерс, за яким «головна рушійна сила життя» та розвитку людини - це прагнення до творчого зростання, розкриття здібностей і підсилення потенціалів, стремління до більшої ефективності, конструктивності й зрілості поведінки [12].

Роль творчої самореалізації у психолого-педагогічному процесі обгрунтовується рядом важливих положень. По-перше, творчість сприяє виробленню вмінь розв'язувати нестандартні завдання, орієнтуватися в нових умовах, переборювати труднощі; по-друге, вона збуджує і стимулює розвиток інтересу до діяльності, оскільки завжди зв'язана з відкриттям нового, знаходженням чогось раніше не відомого. За даними цілої низки спеціальних психологічних досліджень (А. В. Брушлінський, В. В. Давидов, Т. В. Кудрявцев, О. М. Матюшкін, В. О. Моляко, О. К. Тихомиров та ін.) виявлено позитивну роль творчості у стимулюванні пізнавальних інтересів, розвитку мислення, дослідницької активності, здатності до знаходження оригінальних рішень учнями загальноосвітньої і професійної школи.

Творчість також сприяє розвитку оціночно-вимірювальних функцій психіки, які, в свою чергу, допомагають кожному конкретному суб'єкту успішно виробляти в собі моральні, естетичні, інтелектуальні еталони для побудови образів, планів, стратегій своєї поведі- нки і діяльності, а в кінцевому підсумку, свого світогляду й життєвої філософії. Все це визначає характер прийнятих рішень в ігровій, навчальній та трудовій діяльності особистості в період дорослішання.

Творчу особистість дитини не створить педагог-наставник, якщо не буде будувати свою діяльність, насамперед, на творчих засадах. Видатний педагог В. О. Сухомлинський писав, що справжній вчитель не може жити без творчості, однією з необхідних умов якої $є$ вихованість та висока майстерність [13].

Творча самореалізація пов'язана 3 такою важливою формою життя, як спілкуванням. Під час спілкування передаються інформація, досвід. «Якщо діяльність, - пише Г. Щукіна, - всебічно розвиває духовні та фізичні сили людини, то спілкування примножує їх, воно закріплює соціальну спрямованість діяльності. У спілкуванні створюються суттєві для самої особистості відносини» [14].

На думку вчених процес творчої самореалізації відбувається в певному соціальному середовищі, яке створює умови й певним чином визначає характер і зміст діяльності та поведінки кожної особистості [3, 4, 7 ].

Багатство особистості залежить від широти й різноманітності іiї соціальних зв'язків. Включаючи особистість в різноманітну, психолого-педагогічну діяльність різних соціальних об'єднань, у систему широких соціальних зв'язків і формуючи суттєві для неї відносини (до духовних цінностей, до суспільної праці), 
сприяючи накопиченню досвіду особистості (пізнавального, культурного, морального), педагог-психолог отримує можливість стимулювати активність особистості, сприяти трансформації цілей виховання в мотиви, інтереси, установки, ціннісні орієнтації, а отже формувати психологічний простір власного «Я» особистості в цілому $[13,14]$.

Виклад основного матеріалу. Пошук наукового пояснення творчого процесу привів нас до необхідності логічного обгрунтування основних умов самореалізації людини.

Важливо констатувати, що основою процесу творчої самореалізації $€$ особливе прагнення до самовдосконалення як одна 3 вищих потреб особистості, спрямована на постійне зростання можливостей та підвищення якості своєї діяльності й поведінки. Так, С. Л. Братченко, М. Р. Міронова визначають головний зміст самореалізації у звільненні, знаходженні себе й свого життєвого шляху [4]. У дослідженнях Н. Є. Водоп'янової одним із значущих проявів творчої самореалізації розглядається активність життєвої позиції як здатність актуалізувати внутрішні потенціали й можливості, здатність критично переробляти соціальний і особистий життєвий досвід, розвиваючи власну життєву позицію й стратегію життя [6]. В. Є. Клочко та В. А. Красноярцевою показано, що творча самореалізація особистості пов'язана зі спонтанно розвинутою високою «чутливістю до проблем», що є підставою для розвитку схильно- стей до певної діяльності, тобто вони служать підставою стратегічного вибору конкретної діяльності як однієї з важливих у життєдіяльності людини [8]. Таким чином, у проаналізованих наукових позиціях вчених джерелом розвитку особистості в цілому є іiі творча соціальна активність, завдяки якій можлива самореалізація як вищий рівень системної організації людини. Така творча самореалізація можлива в межах того соціуму, що її оточує, й саме він впливає на поведінку людини.

Беручи до уваги ці наукові позиції, визначимо особливості творчої самореалізації людини. Насамперед, уточнимо смислове поле поняття «творча самореалізація особистості». Дійсно, теоретичний аналіз свідчить, що особистість взаємодіє із соціумом не безпосередньо, а опосередковано через призму власного «Я». Сутність творчої самореалізації особистості полягає в інтеріоризації моральних цінностей, смислових орієнтирів, свобод, задекларованих у соціальному світі відносно внутрішнього «Я» особистості. Таким чином, цінності та смисли, об'єктивно існуючі у соціальному просторі, можуть бути відсутніми в системі самоцінності конкретної людини. Адже цінності, смисли, моральні установки завжди суб'єктивні, індивідуальні, своєрідні, враховуючи якісний рівень ціннісного «Я» та їх місце у структурі самоцінності особистості. Саме тому проблема творчої самореалізації полягає не стільки в умовах і розвитку в певному сучасному суспільстві, яке значно різ- 
ниться для кожної соціальної істоти, скільки у способах осмислення людиною певної соціальної реальності, наслідком якої виступає цінність для неї окремої особистісної якості та їі зовнішнього прояву - поведінки.

Узагальнивши наукові позиції психологів (К. Томас, Х. Кіндлер, Н. Пезешкіан, Л. Ф. Бурлачок, Є. Ю. Коржова), щодо визначення стратегій самореалізації можна констатувати наступне: стратегія поведінки - це генеральна лінія поводження, що розгортається у процесі дорослішання, яка спрямована на самоорганізацію й самореалізацію самоцінності особистості. Стратегії поведінки можуть спиратися, на наш погляд, на особистісну компетентність, творчі здібності, уміння. Вироблення особистістю стійких стратегій шляхом самореалізації власного «Я» дозволить їй перейти на новий рівень творчого розвитку. Логічно припустити, що існують певні тенденції у формуванні стратегій самореалізації в той або інший віковий період.

Як відомо, ще А. Адлер виділив два способи творчої самореалізації людини - особистісний i конструктивний. Тоді як згідно Р. Альберті та М. Еммонса існує три основних стратегії самореалізації особистості: 1) невпевнена (адаптативна) поведінка, для якої характерна орієнтація особистості на конформність; 2) асертивна поведінка, заснована на впевненості та незалежності особистості; 3) агресивний стиль поведінки, для якого характерне зневажливе ставлення до інших людей, праг- нення нав'язувати власну думку тощо. Викладені точки зору грунтувалися на тому, що домінування однієї стратегії виключає актуалізацію іншої i, по суті, є критерієм віднесення особистості до тієї або іншої стратегії поведінки [11].

Таким чином, динаміка творчої самореалізації полягає в тому, що незалежно від індивідуальних ліній розвитку, людина реалізує певні стратегії поведінки. Зміна стратегій відповідає певному віковому етапу, коли вирішуються основні завдання віку. Так, наприклад, адаптативна стратегія виявляє себе в некритичному ставленні суб'єкта до дійсності, у потребі встановлювати тісні емоційні зв'язки й бути прихильним до інших людей, у прагненні знайти цінність власного «Я» шляхом ідентифікації із значущими близькими. Агресивна стратегія виявляється у проекції нового досвіду на зовнішні об'єкти, у демонстрації власної цінності та у ії захисті. Конструктивна стратегія самореалізації особистості виявляються у здатності людини підтримувати цінність власного «Я», не знижуючи значущості іншої людини, у вмінні стверджувати себе в реальній діяльності. Актуалізація подібних стратегій співвідноситься із закономірним виникненням, розширенням, узгодженістю ціннісного «Я» у процесі дорослішання. При цьому зазначимо, що конструктивні та альтруїстичні стратегії завжди мають перевагу над іншими, і лише їхнє зменшення на користь адаптативних або егоїстичних стратегій вказує на 
те, що певну поведінку ми можемо віднести до тієї або іншої стратегії (Є. П Нікітін, Н. Є. Харламенкова).

Моделюючи тенезу творчої самореалізації особистості від дошкільного віку до юнацького, можна чітко побачити поступову динаміку системи власного «Я», що пов’язана 3 вибором стратегій творчої самореалізації у процесі дорослішання.

Так, дошкільний вік пов'язаний з початком інтенсивного формування власного «Я» та посиленням адаптативних процесів. У цей період розширюються потенціали для подальшої творчої самореалізації. Творча самореалізація в дошкільному віці відбувається на фоні переживання внутрішньої невідповідності між «Я» реальним та «Я» бажаним. Адаптативна стратегія так само, як і в ранньому віці, дозволяє здійснити самоорієнтування, прийняти нормативне та стандартне в соціальному просторі, здійснити необхідний вибір. Очевидно, адаптативні стратегії поведінки в цей період пов'язані зі складністю прийняття соціальних орієнтирів та формуванням власного «Я». Світ дошкільника поступово стає не тільки сукупністю предметів (рівень предметної самосвідомості), але й світом, що задовольняє іiї напружені творчі потреби (рівень смислової самосвідомості). Осмислюючи розмаїття доброго-поганого, позитивного-негативного, нормативного-аморального у поведінці та взаємодіях, дошкільник відкриває для себе психоло- гічні характеристики оточуючих однолітків та дорослих.

По суті, для дитини стають відкритими власні особистісні якості і накреслюється вищий порівняно 3 попереднім віковим етапом рівень осмислення власного «Я». Самореалізація особистості дошкільника пов'язана зі здатністю означувати себе як слухняний, красивий, розумний, сильний, веселий, охайний. Творчо самореалізуючись, наслідуючи дорослих, дитина привласнює якості дорослих і намагається в сюжетно-рольових іграх презентувати себе через сукупність запозичених у значущих дорослих властивостей. Отже, процес творчої самореалізації дошкільника пов'язаний з імпровізацією в сюжетно-рольовій грі.

Творча самореалізація молодшого школяра відбувається у новій соціальній ситуації - дитина піддається впливу однолітків і першого вчителя. Зі вступом до школи суттєво змінюється ставлення школяра до власного «Я». Усвідомлюючи особливу важливість навчальної діяльності (яка в цей період є провідною), молодший школяр прагне переосмислювати власне «Я», яке піддається соціальним впливам. Він усвідомлює, що зобов'язаний вчитися й у процесі навчання змінювати себе, привласнюючи суспільні знаки (мова, цифри, ноти й ін.), узагальнені поняття, знання та ідеї, що привнесені із суспільного оточення. Водночас він усвідомлює, що відрізняється від інших і переживає унікальність власного «Я», 
прагнучи утвердити його серед дорослих і однолітків.

Ускладнення предметно-осмисленої самосвідомості, поява «осмисленої картини світу» відбувається через засвоєння природи, соціального світу, світу людей, а також через засвоєння різних навчальних дисциплін. Крім того, у молодшого школяра інтенсивно розвивається інтелектуальна рефлексія, внутрішній план дій та довільністю які підвищують показники власного «Я». Навчаючись писати, рахувати, читати, дитина у такому разі зорієнтована на самозміни, опановуючи необхідні засоби розумових дій. Структуруючи власне «Я», вона порівнює себе колишню та нинішню. Найсуттєвіше в навчальній діяльності - рефлексія на власне «Я». «Не знав - знаю», «не вмів умію», «був - став» - ключові оцінки результату поглибленої інтелектуальної рефлексії досягнень і змін власного «Я». Особистісна рефлексія вимагає усвідомлення школярем своїх дій, відбувається закріплення стійких форм поведінки. Організація навчальної діяльність веде до розвитку цілеспрямованості. Якщо у дошкільника творча ігрова діяльність $\epsilon$ провідною, то в молодшому шкільному віці творчість відходить на другий план і з'являється реалістичність самоцінності. Отже, процес творчої самореалізації молодшого школяра пов'язаний, насамперед, 3 інтелектуальною рефлексією та реальними досягненнями в навчальної діяльності.
У підлітковому вічүi відбувається трансформація творчої самореалізації. Підліток намагається протиставити власне «Я» дорослим, відстоювати власну незалежність і самостійність. Творча самореалізація в цей період пов'язана, насамперед, 3 новим емоційноціннісним прагненням - бути і вважатися дорослим. Підліток утверджує власне «Я» у дорослій позиції і дорослих діях, а саме у вилучених з простору дорослих формах поведінки. Різкий стрибок в актуалізації егоїстичних стратегій поведінки обумовлений розв'язанням вікових завдань і новим осмисленням ціннісного «Я» у процесі самореалізації. По суті, застосування егоїстичних стратегій поведінки в цей період обумовлене захистом нового власного «Я» від сильних зовнішніх і внутрішніх впливів.

Відомо, що творче самоствердження підлітка відбувається у просторі інтимноособистісного спілкування з однолітками. Саме у підлітковій спільноті з повною силою реально переживається сутність ролі дорослого. Завдяки саморефлексії й рефлексії на однолітків підліток просувається у напрямку усвідомлення власного «Я» («Хто - Я?»- основне питання віку). Завищені максималістські домагання до власного «Я» і можливість його реалізації перебувають у постійному протиріччі, що призводить до кризи ідентичності. Рефлексивний самоаналіз («Я - у минулому, сьогоденні, майбутньому») відкриває підліткові глибини своєї недосконалості й він переживає 
кризу власного «Я». Отже, творча самореалізація в підлітковому віці пов'язана з самовираженням фізичного «Я». При цьому для самореалізації підліток обирає ту творчу діяльність, яка пов'язана з найбільшими труднощами. Звісно це обумовлено бажанням «пройти через все», заявити про себе («Я $є$ !») та творчо самоствердитися.

В юнацькому віщуі творча самореалізація пов'язана 3 проблемою вибору (професійного, морального, особистісного). У цей період юнак визначає в якій послідовності буде реалізоване власне «Я», зростають його інтелектуальні можливості. Цінність окремих якостей особистості (фізичного «Я», соціального «Я», морального «Я») трансформується в загальну систему. Відбувається оригінальний, творчий (інколи демонстративний) пошук місця власного «Я» у світі. Проте вибір особистісної стратегії поведінки в юнацькому віці більш осмислений та логічно обгрунтований, що пов'язано зі стабілізацією образу реального «Я» та бажаного «Я». Ця стабільність досягається через використання конструктивних стратегій поведінки. Здатність до співпереживання, активне моральне ставлення до людей, природи, розвинута саморефлексія виводить власне «Я» юнака за межі його внутрішнього світу, дозволяючи йому зайняти власну позицію у соціумі. Інтегруючись юнак починає прагнути до духовного самовираження на основі традиційних та нових моральних орієнтацій. Отже, якщо у підлітковому віці переважає мотив твор- чої самореалізації, що характеризує прагнення заявити про себе, то в юнацькому - основним мотивом творчої самореалізації виступає мотив принести користь іншим людям. Відбувається відкриття та творча самореалізація духовного «Я».

\section{Висновки та перспективи подальших} досліджень. Отже, творчість як засіб самореалізації особистості пов'язана з різними стратегіями ï поведінки. При цьому творчість визначається нами як процес нових якісних змін особистості, що актуалізується нею за допомогою усвідомлення власного «Я», об’ єктивуючись у значущих результатах діяльності. Моделюючи прочес творчої самореалізації людини від дошкільного віку до юнацького, можна чітко побачити поступову динаміку системи внутрішнього «Я», що пов’язана $з$ вибором стратегій поведінки у період дорослішання.

Проведене дослідження не вичерпує всіх аспектів даної проблеми. Перспективи подальшого пошуку полягають у з'ясуванні гендерних особливостей та характеристик різних стратегій творчої самореалізацій, а також виявлення їх взаємозв'язку із ціннісними орієнтаціями особистості у період дорослішання.

\section{Перелік використаних джерел:}

1. Аверина И. С., Щебланова Е.И. Краткий тест творческого мышления, фигурная форма / И.С. Аверина, Е.И. Щебланова // Пособие для школьных психологов. М.: Просвещение, 1995. - 150с. 
2. Бабаева Ю. Д., Войскунский А.Е. Одаренный ребенок за компьютером / Ю.Д. Бабаева, А.Е. Войскунский // М.: Прогресс, 2003. - 147c.

3. Братусь Б. С. Русская, советская, российская психология: Конспективное рассмотрение / Б.С. Братусь // М.: Московский психолого-социальный институт; Флинта, 2000. - 88c.

4. Братченко С. Л., Миронова М.Р. Личностный рост и его критерии // Психологические проблемы самореализации личности /Под ред. А.А. Крылова, Л.А. Коростылевой. СПб, 1997. -160с.

5. Буш Г. Диалектика и творчество / Г. Буш / - Рига: Слово, 1985. - 189с.

6. Водопьянова Н. E. Активная жизненная позиция личности и профессиональная адаптация в условиях социально-економического кризиса / Н.Е. Водопьянова // Психологические проблемы самореализации личности. M., 1998. - 180c.

7. Галажинский Э. В. Проблема уровней самореализации человека: ценностно-смысловой контекст / Э.В. Галажинский // Ценностные основания психологической науки и психология ценностей. - М.: ИЗД-во «Институт психологии РАН», 2088. - С.123-147.

8. Клочко A. B., Краснорядцева О.М. Суверенность как результат становления человека в совмещенной психологической системе / А.В. Клочко, О.М. Краснорядцева // Вестник БГПУ: Психолого-педагогические науки. 2001. - № 1. - C.4-9.

9. Маслоу А. Мотивация и личность // Психология личности в трудах зарубежных психологов. - СПб: Питер, 2000. - C.183-198.

10. Нартова-Бочавер С. К. Человек суверенный: психологическое исследование человека в его бытии / С.К. Нартова-Бочавер // СПб.: Питер, 2008. - 400 с.

11. Никитин Е. П., Харламенкова Н.Е. Феномен человеческого самоутверждения / Е.П. Никитин, Н.Е. Харламенкова // СПб.: Алтея, 2000. - 230с.

12. Роджерс $K$. Взгляд на психотерапию. Становление человека / Общ. ред. Е.И. Исенина. - М.: Прогресс, 1994. $-480 \mathrm{c}$.
13. Сухомлинський В. О. Сто порад учителеві / В.О. Сухомлинський // -К.: Радянська школа, 1988. - 310с.

14. Щукина Г. И. Активизация познавательной деятельности учащихся в познавательном процессе / Учеб. пособие. - М.: Просвещение,1979. - 160с.

\section{References (Transsliteration):}

1. Averina I. S., Shheblanova E.I. (1995) Kratkij test tvorcheskogo myshlenija, figurnaja forma.[Short test of creative thinking, figured form.]Moscow: Prosveshhenie

2. Babaeva Ju. D., Vojskunskij A.E. (2003) Odarennyj rebenok za komp'juterom. [A gifted child at the computer.]. Moscow: Progress.

3. Bratus B. S. (2000) Russkaja, sovetskaja, rossijskaja psihologija: Konspektivnoe rassmotrenie. [Russian, Soviet, Russian psychology: A concise consideration]. Moscow: Moskovskij psihologo-social'nyj institut; Flinta.

4. Bratchenko S. L., Mironova M.R. (1997) Lichnostnyj rost i ego kriterii. Psihologicheskie problemy samorealizacii lichnosti. [Personality growth and its criteriaю Psychological problems of self-realization of personality]. A.A. Krylova, L.A. Korostyleva (Ed.).St.Petersburg

5. Bush G. (1985). Dialektika i tvorchestvo. [Dialectics and creativity.] Riga: Slovo.

6. Vodop'janova N. E. (1998) Aktivnaja zhiznennaja pozicija lichnosti i professional'naja adaptacija $\mathrm{v}$ uslovijah social'no-ekonomicheskogo krizisa. Psihologicheskie problemy samorealizacii lichnosti. [Active life position of the individual and professional adaptation in the conditions of social and economic crisis. Psychological problems of self-realization of personality]. Moscow.

7. Galazhinskij Je. V. (1988) Problema urovnej samorealizacii cheloveka: cennostno-smyslovoj kontekst. Cennostnye osnovanija psihologicheskoj nauki i psihologija cennostej. [The problem of human self-realization levels: the value-semantic context. Values of the foundation of psychological science and the psychology of values].Moscow: «Institut psihologii RAN». 
8. Klochko A. V., Krasnorjadceva O.M. (2001) Suverennost' kak rezul'tat stanovlenija cheloveka $\mathrm{v}$ sovmeshhennoj psihologicheskoj sisteme. [Sovereignty as a result of the formation of a person in a combined psychological system]. Vestnik BGPU: Psihologo-pedagogicheskie nauki Bulletin of the Belarusian State Pedagogical University: Psychological and Pedagogical Sciences, 2, 4-9.

9. Maslou A. (2000). Motivacija i lichnost'. Psihologija lichnosti $\mathrm{v}$ trudah zarubezhnyh psihologov. [Motivation and personality. Psychology of personality in the works of foreign psychologists]. St.Petersburg: Piter.

10. Nartova-Bochaver S. K. (2008) Chelovek suverennyj: psihologicheskoe issledovanie cheloveka $\mathrm{v}$ egobytii. [A sovereign man: a psychological study of a man in his being]. St.Petersburg: Piter.

11. Nikitin E. P., Harlamenkova N.E. (2000) Fenomen chelovecheskogo samoutverzhdenija. [The phenomenon of human self-affirmation]. St.Petersburg: Alteja.

12. Rodzhers K. (1994) Vzgljad na psihoterapiju. Stanovlenie cheloveka. [A look at psychotherapy. The formation of man]. E.I. Isenina (ed.). Moscow: Progress.

13. Sukhomlynskyi V. O. (1988) Sto porad uchytelevi. [One hundred tips for the teacher]. Kyiv: Radianska shkola.

14. Shhukina G. I. (1979) Aktivizacija poznavatel'noj dejadetel'nosti uchashhihsja $\mathrm{v}$ poznavatel'nom processe. [Activation of the cognitive activity of students in the cognitive process]. Moscow: Prosveshhenie.

\section{Prosandeeva Lyudmila}

Doctor of Psychology, Head of the Department of Psychology of Kyiv National University of Culture and Arts, Kiev (Ukraine)

\section{CREATIVITY AS A MEANS OF SELF-REALIZATION OF AN ADULT PERSONALITY}

\section{ABSTRACT}

Creativity development is an inherent part of a person's joining the social space. In the social space, maturing personality simultaneously discovers and masters social values and points, fills it with sense.

Indeed, the qualitative new creative level formation is caused by the transformation of emanating activity into creative one that is more significant for a person and appropriate for the person's self-realization in creativity.

Theoretical analysis became the grounds of foreign scholars' view qualitative interpretation on the human's creative self-realization of self-orientations and efforts to prove oneself the abilities and skills. Thus, A. Maslow determines creative self-realization as a self-actualization, commitment. K. Rodgers is of the same opinion. He stated that attempting to grow, to develop inner abilities, to strength creative potentials and aiming to better effectiveness and constructiveness are the "main promoting power of life" and human's creative development.

Creative self-realization dynamic claims that a person, independently from life lines development is realized by some behavior strategies ajested - non-ajested, altruistic - selfish, construc- 
tive - destructive. The strategy change is specific to certain age, when the main age tasks are settled in. Actualization of such creative self-realization certain strategies is coherent with the logical appearance, spreading and harmonization of oneself in the growing up process. However, it should be noted that constructive and altruistic strategies always have priority over the others.

Thus, creativity as a personality's selfrealization fact is connected with different behavior strategies. Creativity is determined as a process of personality's qualitative changes which are provided by awareness, realized by significant activity results. Modeling the human creative self-realization process since the pre-school period until adolescence age we can clearly see gradual dynamic of inner "I" system, connected with the behavior strategies choice in the growing up process.

Key words: creativity, self-realization of personality, dynamics of creative self-realization, strategy of self-realization.

\section{Просандеева Людмила Евгеньевна}

Доктор психологических наук, заведующиии кафедрой психологии Киевского начионального университета культуры и искусств, г. Киев (Украина)

\section{ТВОРЧЕСТВО КАК СРЕДСТВО САМО- РЕАЛИЗАЦИИ ЛИЧНОСТИ ПЕРИОД ВЗРОСЛЕНИЯ}

Аннотация. Развитие творчества неотделимо от процесса вхождения личности в социальное пространство. В социальном пространстве личность периода взросления одно- временно открывает и осваивает общественные ценности и смыслы, наделяет их собственным содержанием.

Несмотря на достаточно основательную базу исследований, заявленная проблема все еще требует изучения, особенно учитывая состояние психологической культуры в украинском обществе. Поэтому целью статьи является раскрытие творчества как средства самореализации личности в период взросления, а именно: моделирование процесса творческой самореализации человека от дошкольного возраста к юношескому.

Важно констатировать, что основой процесса творческой самореализации является особое стремление к самосовершенствованию как одна из высших потребностей личности, направленная на постоянный рост возможностей и повышения качества своей деятельности и поведения.

Безусловно, становление качественно нового уровня развития творчества обусловлено трансформацией исходной деятельности в творческую, более значимую для человека деятельность, соответствующую ее потребности в самореализации.

Проведенный теоретический анализ стал основой качественной интерпретации взглядов зарубежных ученых на процесс творческой самореализации человеком своих смысложизненных ориентаций, попытки самоствердитисвои способности и способности. Такую творческую самореализацию А. Мас- 
лоу называл самоактуализацией, самоотдачей, самореализации. Подобной точки зрения придерживался и К. Роджерс, согласно которому «главная движущая сила жизни» и творческого развития человека - это стремление к росту, раскрытие способностей и усиления творческих потенциалов, стремление к большей эффективности, конструктивности.

Динамика творческой самореализации состоит в том, что независимо от индивидуальных линий развития, человек реализует определенные стратегии поведения - адаптативного-неадаптативну, альтруистическоеэгоистическую, конструктивную-деструктивную. Изменение стратегий соответствует определенному возрастному этапу, когда решаются основные задачи возраста. Актуализация подобных стратегий творческой самореализации соотносится с закономерным возникновением, расширением, согласованностью собственного «Я» в процессе взросления. При этом отметим, что конструктивные и альтруистические стратегии всегда имеют преимущество перед другими.

Итак, творчество как средство самореализации личности связана с различными стратегиями его поведения. Творчество определяется нами как процесс качественных изменений личности, актуализируется ней посредством осознания собственного «Я», объективируясь в значимых результатах деятельности. Моделируя процесс творческой самореализации человека от дошкольного возраста к юношескому, можно четко увидеть постепенную динамику системы внутреннего «Я», связанная с выбором стратегий поведения в период взросления.

Ключевые слова: творчество, самореализация личности, динамика творческой самореализации, стратегии самореализации.
Дата отримання статті: 21.05.2018 Дата рекомендації до друку: 15.06.2018 Дата оприлюднення: 02.07.2018 